\title{
Decadent Sporulation Mutants of Bacillus subtilis
}

\author{
By GEORGES BALASSA* AND PIERRE MILHAUD \\ Unité de Microbiologie, C.N.R.S., Montpellier, France \\ J. C. F. SOUSA AND M. T. SILVA† \\ Centre of Experimental Cytology, University of Porto, Porto, Portugal
}

(Received 26 May 1978; revised 9 August 1978)

\begin{abstract}
In decadent sporulation mutants, sporulating populations are heterogeneous: the cells reach successive chemical and physical resistances with progressively decreasing frequencies. Each decadent mutant can be characterized by the shape and slope of the curve describing the frequency of cells resistant to various agents ('the resistance spectrum'). In some mutants the resistance spectrum decreases progressively from xylene resistance to heat resistance; in other mutants it decreases rapidly between octanol resistance and chloroform resistance. Electron microscopy showed that in two mutants the majority of the cells are blocked at stages III and IV; the number of cells that develop further to reach successive morphological stages falls off progressively. In two other mutants most cells reach stage V. Cortexless spores are also frequent. One of the decadent mutations, $S p o L 1$, was localized between aroD and acf. The phenotype of decadent mutants is discussed in terms of sequential gene activation.
\end{abstract}

\section{INTRODUCTION}

Sporulation mutants can be characterized in general by the last morphological stage reached by the sporulating cells. Mutants blocked at any of the morphological stages from 0 to VI have been found (reviewed by Balassa, 1971; Piggot \& Coote, 1976). Normally the block is clearly defined: the majority of the cells reach a given stage, and no cells undergo further development. [Cells in which sporulation stops earlier than this stage are, however, frequently present (see Balassa \& Yamamoto, 1970).] In a study of the sequential development of chemical resistances in sporulating cells, a peculiar mutant (DB16) was found in which the majority of the cells reached only stage III or IV, but rare cells reached octanol resistance and even chloroform resistance with frequencies of about $10^{-2}$ and $10^{-4}$, respectively (Balassa \& Yamamoto, 1970; Balassa et al., 1974). Apparently in this mutant successive steps of spore formation are reached with decreasing frequencies. Such a phenotype will be called 'decadent'. ('Decadence: the process of...declining, decay, impaired condition' - Shorter Oxford English Dictionary. This term seems more appropriate than the previously used term 'attenuation'.) Recognition of decadent mutants is based on the stepwise decrease in the frequency of spores resistant to the successive chemical treatments. The purpose of this paper is to present a detailed morphological, physiological and genetic study of mutant DB16. In addition eight other, newly described decadent mutants are characterized phenotypically.

Sporulation genes are under a common genetic control and their expression is submitted to one-directional pleiotropy: each gene controls the activation of all the 'later' but none

* Present address: 10 Impasse Pierre Rouge, 34000 Montpellier, France.

† Present address: 1021 Rua do Campo Alegre, Porto, Portugal. 
of the 'earlier' genes (Balassa, 1969, 1971; Balassa \& Yamamoto, 1970; Piggot \& Coote, 1976). We believe that the decadent phenotype is due to some type of regulatory mutation and reflects an alteration in the mechanism of sequential gene activation.

\section{METHODS}

Strains. Strain DB16 (Institut Pasteur Culture Collection no. 7627) was obtained by $N$-methyl- $N^{\prime}$-nitro$N$-nitrosoguanidine-induced mutagenesis of germinated spores (Balassa, 1969). Strains FA10 (IPCC no. 7628), FD10 (IPCC no. 7629) and FE9 (IPCC no. 7630) were obtained in a similar manner (J. Zucca \& G. Balassa, unpublished). Strains SE10,11, 12,13 and 16 were isolated as late sporulation mutants from ultraviolet-irradiated spores of the original Marburg (SMY) strain (Millet \& Ryter, 1972).

Sporulation. This was achieved in nutrient broth as described previously (Balassa, 1969; Dod et al., 1978). Time $t_{0}$ was defined as the end of exponential growth; $t_{1}, t_{2}$ etc. indicate sporulation times in hours after $t_{0}$.

Chemical treatments. These were done as described by Milhaud \& Balassa (1973). Undiluted samples of sporulating cultures, at $t_{24}$ unless otherwise specified, were treated for $15 \mathrm{~min}$ at room temperature with $0 \cdot 1 \mathrm{vol}$. of organic solvents $[90 \%(\mathrm{v} / \mathrm{v})$ ethanol was used]. Trichloroacetic acid (TCA) resistance was measured after incubating the cells at $4{ }^{\circ} \mathrm{C}$ with $5 \%(\mathrm{w} / \mathrm{v}) \mathrm{TCA}$. Heat resistance was measured by incubating samples of cultures at $80^{\circ} \mathrm{C}$ for $10 \mathrm{~min}$.

Genetic methods. Transformation and transduction (by phage PBS1) were done as described by Milhaud et al. (1978). The chloroform replica technique consisted of replicating agar plates with velvet before and after exposure to chloroform vapour $(30 \mathrm{~min}$ ) and identifying the colonies present on the first replica but absent from the second after incubation.

Electron microscopy. Cells were sampled at the times indicated, fixed according to the Ryter \& Kellenberger (1958) procedure and embedded in Epon as described by Sousa et al. (1974). Thin sections were photographed and at least 100 sporulating cells were examined in each section. The morphological stages II (membrane invagination), III (enclosed forespore), IV (cortex), V (coat development) and VI (mature spore) were identified according to Ryter (1965) and Balassa (1971). Both longitudinal and transverse sections were counted (Sousa et al., 1978). The frequency of cells at each morphological stage was calculated as the percentage among the total number of sporulating cells; cells which did not show any sign of spore formation were excluded from the calculation (Sousa et al., 1978).

\section{RESULTS}

\section{Phenotypic characterization of decadent mutants}

\section{Spectrum of chemical resistances}

In cells which sporulate normally, resistances to various chemicals develop sequentially, before heat resistance, in the order: xylene, toluene, octanol, chloroform (Milhaud \& Balassa, 1973). Thus earlier stages of spore development can be associated with 'early resistances' and later stages with 'late resistances'. Treatment of samples from sporulating cultures with various agents allows one to measure the number of the forespores which have reached a given stage of spore formation. Such 'resistance spectra' were obtained at $t_{24}$ for cultures of nine decadent mutants, using five organic solvents and heat treatment. Although the actual survival values varied considerably from one experiment to another (Table 1), this did not alter the order in which the frequency of cells resistant to different agents decreased or the general shape of the resistance spectra.

For each mutant a typical resistance spectrum was obtained by calculating the geometrical mean (antilogarithm of the mean of the logarithms of the survivals values) of at least two, and in general five to eleven, experiments (Fig. 1). The nine mutants exhibited a variety of resistance spectra. In most of them the decadence, i.e. the decrease in the frequency of survival from one resistance to the next, was progressive, but it occurred at different rates; it was fast in SE12, where no cells became octanol-resistant, and slow in SE11, where cells became heat-resistant at a frequency of $10^{-3}$. In DB16 and FD10, however, there was a sudden decrease in frequency between octanol resistance and chloroform resistance. Thus each mutation defines genetically the resistance spectrum of the strain. 


\section{Table 1. Intermediate chemical resistances of strain DB16}

Sporulating cultures were treated at $t_{24}$ with the chemicals indicated, or heated to $80^{\circ} \mathrm{C}$ for $10 \mathrm{~min}$. The results indicate the number of cells $\mathrm{ml}^{-1}$ surviving.

Treatment

Octanol
Butanol
Methanol
Ethanol
Acetone
Dioxan
Chloroform
TCA
$80^{\circ} \mathrm{C}, 10 \mathrm{~min}$

\section{Expt 1}

$$
\begin{array}{r}
2.9 \times 10^{7} \\
3.6 \times 10^{6} \\
3.7 \times 10^{5} \\
3 \cdot 2 \times 10^{5} \\
4 \times 10^{5} \\
7 \cdot 5 \times 10^{4} \\
6 \cdot 3 \times 10^{4} \\
5 \cdot 2 \times 10^{4} \\
2 \times 10^{3}
\end{array}
$$

\section{Expt 2}

$4 \times 10^{6}$

$1.5 \times 10^{5}$

$7 \times 10^{3}$

$7 \times 10^{3}$

$8.5 \times 10^{3}$

$2 \cdot 5 \times 10^{3}$

$5 \times 10^{2}$

ND

$6 \times 10^{2}$

\section{Expt 3}

$5 \times 10^{6}$

$2 \cdot 4 \times 10^{6}$

$3 \times 10^{4}$

$3 \times 10^{4}$

$1 \times 10^{4}$

$4 \times 10^{3}$

$4 \times 10^{2}$

$3 \times 10^{2}$

$6 \times 10^{2}$

ND, Not determined.

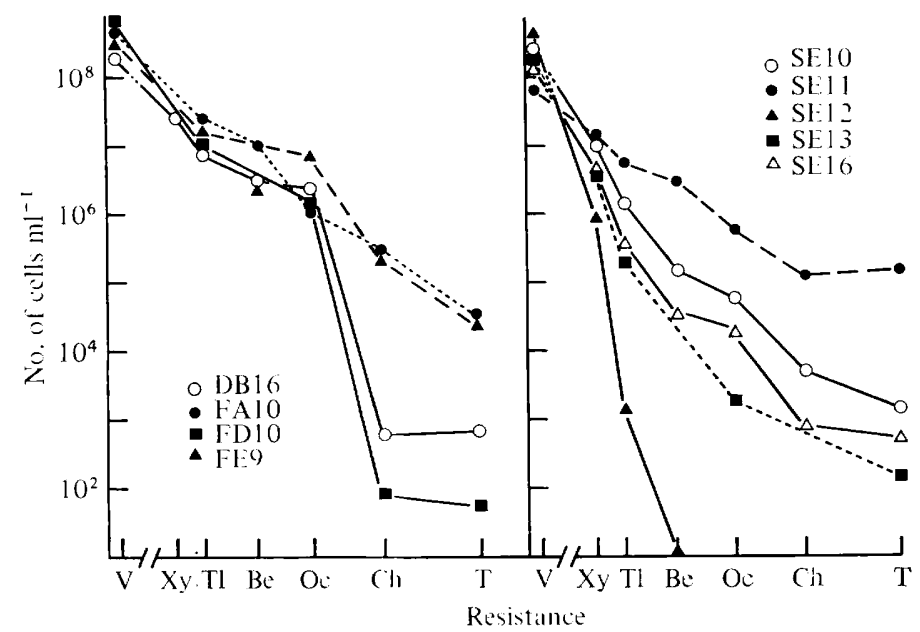

Fig. 1. Resistant spectra of decadent mutants. Samples of sporulating cultures at $t_{24}$ were tested for resistance to xylene (Xy), toluene $(\mathrm{Tl})$, benzene $(\mathrm{Be})$, octanol $(\mathrm{Oc})$, chloroform $(\mathrm{Ch})$ and to heating at $80^{\circ} \mathrm{C}$ for $10 \mathrm{~min}(\mathrm{~T})$; $\mathrm{V}$ denotes results for viable cells. The numbers of cells surviving each treatment (geometrical mean values) are shown. The distances on the horizontal axes are proportional to the time of appearance of the resistances in wild-type cells (Milhaud \& Balassa, 1973).

In addition to the chemicals mentioned in Fig. 1, normal sporulating cells become progressively resistant to other organic solvents and acids (Milhaud \& Balassa, 1973). Thus resistance to butanol appears after octanol resistance, resistances to chloroform, methanol, ethanol, acetone and dioxan appear at about the same time, while TCA resistance and heat resistance appear later. Resistance to these agents was measured in three experiments with DB16 (Table 1). Butanol resistance closely followed octanol resistance. The frequencies of cells resistant to methanol, ethanol, acetone and dioxan were similar, being intermediate between the frequencies of octanol-resistant and chloroform-resistant cells. The number of cells surviving TCA treatment was between the numbers surviving chloroform and heat treatments. These observations confirm the order of the resistances obtained by kinetic experiments with the wild-type strain. Although sporulation of decadent mutants might be slower than sporulation of the wild type (see below), this is not the reason for the low frequencies of resistant cells at $t_{24}$ : the frequency of heat-resistant spores was the same in $t_{24}$ and $t_{48}$ samples of four decadent mutants tested (DB16, FA10, FD10 and FE9).

Sporulation is frequently temperature-sensitive, particularly among oligosporogenous mutants, and few cells sporulate at high incubation temperatures. This was not the case for 
Table 2. Frequency of morphological stages in sporulating cultures of decadent mutants

The frequencies are expressed as percentages of the total number of sporulating cells. In each sample, 200 or more cells were counted. Stage VI cells include both enclosed and free, apparently mature, spores. Results for strain 168, which sporulates normally, are included for comparison.

\begin{tabular}{|c|c|c|c|c|c|c|c|}
\hline \multirow[b]{2}{*}{ Strain } & \multirow{2}{*}{$\begin{array}{l}\text { Time of } \\
\text { sampling }\end{array}$} & \multirow{2}{*}{$\begin{array}{l}\text { Percentage } \\
\text { of cells in } \\
\text { sporu- } \\
\text { lation }\end{array}$} & \multicolumn{5}{|c|}{ Percentage of cells at stage: } \\
\hline & & & II & III & IV & $\mathrm{V}$ & VI \\
\hline DB16 & $\begin{array}{l}t_{6} \\
t_{10}\end{array}$ & $\begin{array}{l}33 \\
30\end{array}$ & $\begin{array}{l}3 \\
7\end{array}$ & $\begin{array}{l}84 \\
41\end{array}$ & $\begin{array}{l}13 \\
37\end{array}$ & $\stackrel{0}{15^{*}}$ & $\begin{array}{l}0 \\
0\end{array}$ \\
\hline FA10 & $t_{24}$ & 69 & 1 & 8 & 3 & 59 & 30 \\
\hline FD10 & $t_{6}$ & 44 & 1 & 62 & 36 & $2^{*}$ & 0 \\
\hline FE9 & $t_{24}$ & 74 & 2 & 6 & 4 & 58 & 31 \\
\hline 168 & $\begin{array}{l}t_{6} \\
t_{20}\end{array}$ & $\begin{array}{l}96 \\
92\end{array}$ & $\begin{array}{l}0 \\
0\end{array}$ & $\begin{array}{l}1 \\
0\end{array}$ & $\begin{array}{l}3 \\
1\end{array}$ & $\begin{array}{r}27 \\
2\end{array}$ & $\begin{array}{l}68 \\
84\end{array}$ \\
\hline
\end{tabular}

DB16 and FE9, as the same resistance spectra were obtained when these mutants were incubated at 30,37 and $45^{\circ} \mathrm{C}$.

Dipicolinic acid (DPA), a late sporulation product presumably related to heat resistance (see Gould \& Dring, 1974; Balassa et al., 1979), was synthesized only in low amounts: $t_{24}$ cultures of DB16 and FE9 contained 8 and $6 \mu \mathrm{g} \mathrm{DPA} \mathrm{ml}{ }^{-1}$, respectively, compared with $40 \mu \mathrm{g} \mathrm{ml}^{-1}$ in wild-type cultures. Addition of DPA $\left(100 \mu \mathrm{g} \mathrm{ml}^{-1}\right)$ to sporulating cultures of decadent mutants at $t_{0}$ or $t_{3}$ did not change their resistance spectra.

The production of the sporulation-associated extracellular protease was measured as described by Dod et al. (1978). Two of the decadent mutants, DB16 and FD10, had normal protease activities: $0 \cdot 10$ and $0 \cdot 13$ units $\mathrm{ml}^{-1}$, respectively, at $t_{24}$, compared with $0 \cdot 10$ units $\mathrm{ml}^{-1}$ in $\mathrm{Spo}^{+}$cultures. A third strain, FE9, overproduced protease due to the presence of an independent spore control mutation, Sco15 (Milhaud et al., 1978).

\section{Morphological characterization}

Chemical resistances can be used to characterize the small fraction of the population in cultures of decadent mutants which reach the latest stage of sporulation. In contrast, electron microscopy shows the stages reached by a large number of cells. The sporulation of four decadent mutants was studied morphologically in samples taken at $t_{6}, t_{10}$ and $t_{24}$ (Table 2). At $t_{6}$, most of the cells in cultures of a $\mathrm{Spo}^{+}$strain (168) had reached stage VI, whereas the populations of the four decadent mutants remained heterogeneous. In DB16, the most typical cells showed stage III forespores surrounded by an abnormally thick germ cell wall and enclosed in a lysed sporangium (Fig. 2). Only one-third of the cells reached stage IV and even less attained stage V. In the latter, both the cortex and the coats appeared to be incomplete and immature. For instance, the typical lamellar structure of the inner spore coat was missing (Figs 3,4). This early stage V, characterized by apparently abnormal assembly of the cortex and of the spore coats, is indicated as 'stage $\mathrm{V}$ ' in the quantitative studies (Table 2, Fig. 9). (It is possible that the cortex and the coats were present in DB16 cells more frequently than observed but were rapidly degraded.) Cells of FD10 showed the same characteristics as DB16.

In contrast, FA10 and FE9 cells generally reached stage V and frequently stage VI (Figs 5 to 7). Both the inner and outer spore coats were well developed and apparently mature. The ribosomes of the spore cytoplasm remained clearly visible even in stage VI spores, as they are in the chloroform-resistant but heat-sensitive spores of a dpa mutant but not in DPA-containing heat-resistant spores (Balassa et al., 1979). Moreover, the cortex was 

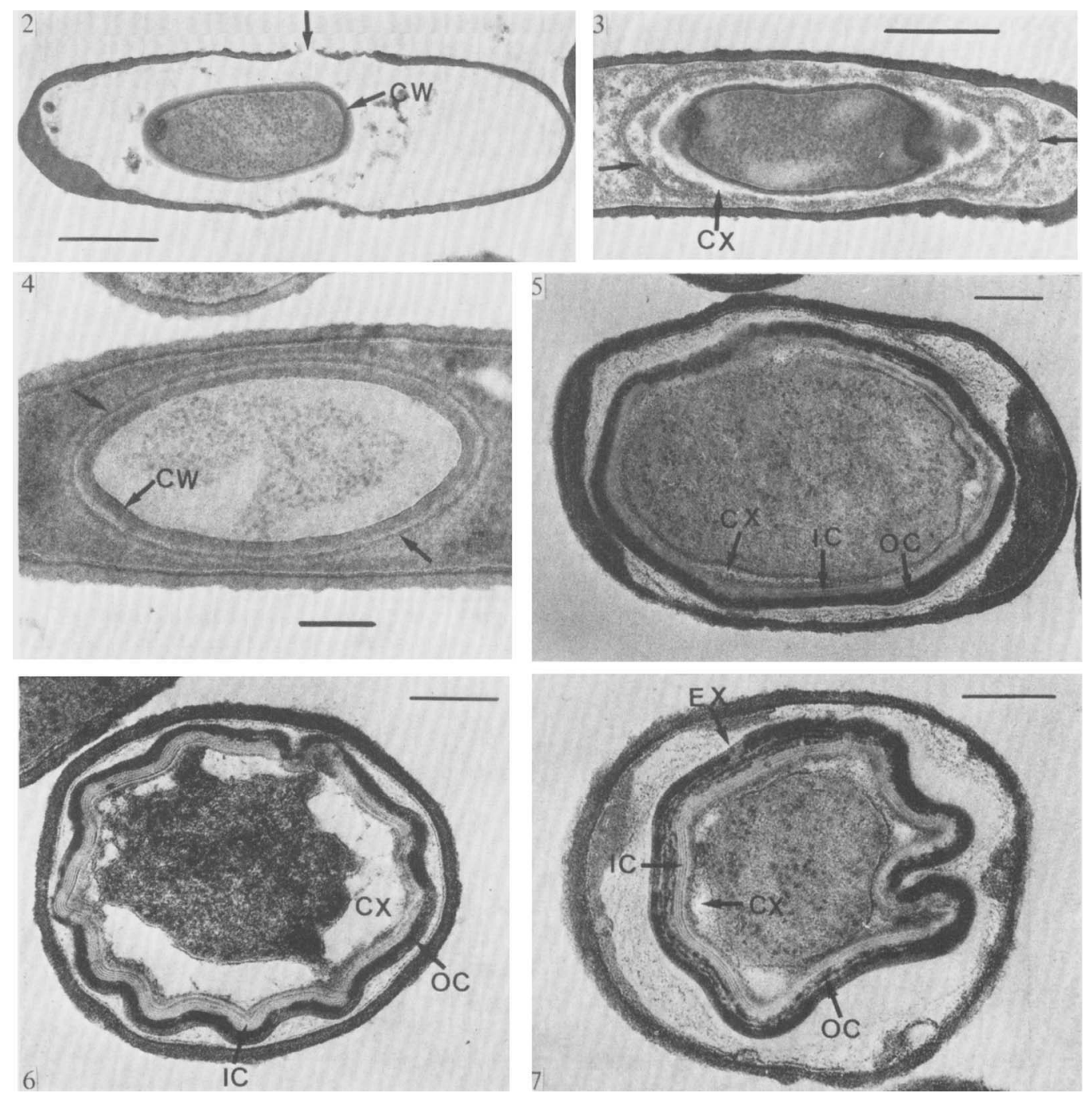

Bar markers represent $0.5 \mu \mathrm{m}$ in Figs 2 and 3 and $0.2 \mu \mathrm{m}$ in Figs 4 to 7 .

Figs 2 to 7. Thin sections of spores of decadent mutants sampled at $t_{32}$ (strain DB16) or $t_{24}$ (strain FE9): $\mathrm{CW}$, germ cell wall; $\mathrm{CX}$, cortex or cortex region; IC, inner spore coat; OC, outer spore coat; EX, exosporium.

Fig. 2. Strain DB16, stage III forespore surrounded by a thick germ cell wall. The sporangium is completely lysed. The unlabelled arrow indicates lysis of the sporangial cell wall.

Fig. 3. Strain DB16, early stage V. An incomplete cortex and abnormal, immature spore coat (unlabelled arrows) are present. The sporangium is partially lysed.

Fig. 4. Strain DB16, abnormal stage V. This is the most advanced stage reached by this strain. An incomplete coat is present (unlabelled arrows). Between the thick germ cell wall and the immature coat some cortex-like material can be seen.

Fig. 5. Strain FE9, late stage V. The cortex is reduced to an irregular layer of granular material. The irregular outline of the spore coats suggests that they have been assembled in the absence of a well developed cortex.

Fig. 6. Strain FE9, stage VI. The cortex is missing; the empty areas suggest that it was disorganized and lysed after coat assembly. The coats appear to be mature but highly convoluted. (Transverse section.)

Fig. 7. Strain FE9, stage VI. The coats appear to be mature but highly convoluted as in Fig. 6 . The cortex is missing; in some places some granular material (incomplete or partially destroyed cortex?) can be seen. (Transverse section.) 


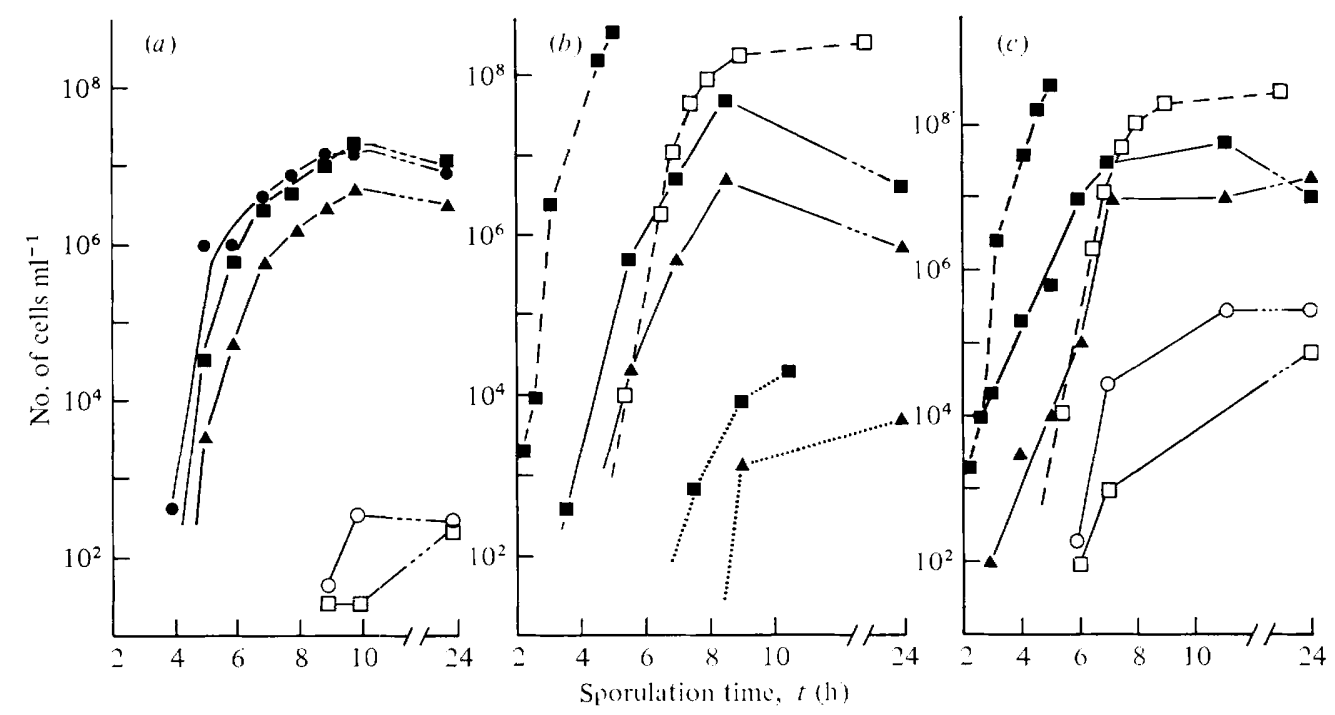

Fig. 8. Development of chemical resistances in (a) strain DB16 (-), (b) strains FA10 (- - ) and FD10 $(\cdots \cdots)$ and $(c)$ strain FE9 $(-)$. Data for control Spo cultures (---) are included in $(b)$ and $(c)$. Results show the numbers of cells resistant to xylene $(\boldsymbol{O})$, toluene $(\boldsymbol{\square})$, octanol $(\boldsymbol{\Delta})$, chloroform $(\bigcirc)$ and heat, $80^{\circ} \mathrm{C}$ for $10 \mathrm{~min}(\square)$.

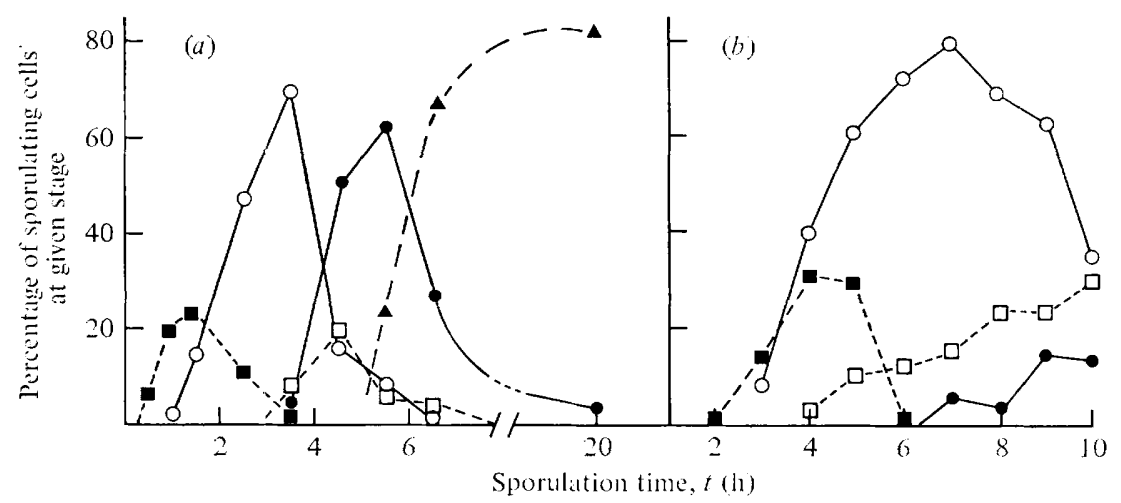

Fig. 9. Morphological development of (a) strain 168, wild type (from Sousa et al., 1978) and (b) strain DB16. The numbers of cells at stages II $(\boldsymbol{\square}), \mathrm{III}(\bigcirc), \mathrm{IV}(\square), \mathrm{V}(\boldsymbol{O})$ and VI $(\boldsymbol{\Delta})$ are expressed as percentages of the total number of sporulating cells. With strain DB16 $(b)$ 'stage $V$ ' cells are blocked at early stage $\mathrm{V}$ (see text).

abnormal or missing completely: in an FA10 culture, $70 \%$ of the cells which reached stage V were cortex-less at $t_{24}$. This abnormal appearance might well be due to the degradation of a pre-existing but unstable cortex. The spore coats in these cortex-less spores were convoluted.

No free spores or forespores were found in cultures of the decadent mutants. Apparently sporulation-dependent lysis of the sporangial cell wall did not take place.

\section{Kinetics of development of decadent mutants}

The development of the chemical resistances was followed in sporulating cultures of four decadent mutants (Fig. 8). All the resistances appeared later in the mutants and the number of resistant cells increased more slowly than in control $\mathrm{Spo}^{+}$cultures. Moreover, the delay was longer and the increase was slower in the most decadent mutants (i.e. those 
Table 3. Genetic mapping of SpoL1 in three-factor crosses

The donor was strain AA32 (hisB2 SpoL1).

\begin{tabular}{|c|c|c|c|}
\hline $\begin{array}{l}\text { Genotype of } \\
\text { recipient }\end{array}$ & $\begin{array}{l}\text { Selected } \\
\text { marker }\end{array}$ & $\begin{array}{l}\text { No. of } \\
\text { transductants } \\
\text { selected }\end{array}$ & $\begin{array}{l}\text { Percentage } \\
\text { cotransfer* }\end{array}$ \\
\hline $\begin{array}{l}\text { metC3 pheAI pyrAI } \\
\text { (PM12) }\end{array}$ & $\begin{array}{l}\text { Phe } \\
\text { Ura }\end{array}$ & $\begin{array}{l}449 \\
400\end{array}$ & $\begin{array}{r}14 \\
0\end{array}$ \\
\hline $\begin{array}{l}\text { leu-8 phe } A \text { trpC } 2 \\
\text { (PM14) }\end{array}$ & $\begin{array}{l}\text { Phe } \\
\text { Leu }^{+} \\
\text {Trp }^{+}\end{array}$ & $\begin{array}{l}281 \\
229 \\
350\end{array}$ & $\begin{array}{c}17 \cdot 5 \\
2 \\
0\end{array}$ \\
\hline $\begin{array}{l}\operatorname{argA11} \text { lys-1 metC3 } \\
\text { (PM40) }\end{array}$ & $\begin{array}{l}\text { Lys } \\
\text { Arg }\end{array}$ & $\begin{array}{l}224 \\
300\end{array}$ & $\begin{array}{l}4 \\
0\end{array}$ \\
\hline $\begin{array}{l}\text { acf aroD } \operatorname{trp} C 2 \\
\text { (PM49) }\end{array}$ & AroD $^{+}$ & 344 & 91 \\
\hline $\begin{array}{l}\text { acf pheA trpC2 } \\
\text { (PM47) }\end{array}$ & Phe & 583 & 15 \\
\hline
\end{tabular}

in which the final frequency of resistant cells was lowest) and with the last resistances reached. To summarize, the lower the final frequency of spores resistant to a treatment, the later this resistance appeared and the slower the number of resistant cells increased.

Morphogenesis was also followed in a DB16 culture by quantitative electron microscopy. Compared with the development of wild-type cultures, all the morphological stages appeared later and persisted for a longer period (Fig. 9). This was particularly obvious for stage III cells which accumulated from $t_{4}$ to $t_{7}$ and remained present beyond $t_{10}$. The number of cells which reached stages IV and V increased slowly from $t_{4}$ and $t_{7}$, respectively. These results again suggest that in decadent mutants the switch from one morphological stage to the next is delayed and occurs with a low probability.

\section{Genetic studies of decadent mutants}

\section{Genetic homogeneity of the populations}

Decadent mutants were recognized because their spores reached 'early chemical resistances' more frequently than 'late resistances' or heat resistance. Population heterogeneity of the sporulating cultures might have been due to genetic heterogeneity. However, this was not the case since clones isolated from DB 6 colonies obtained by plating untreated cultures (clones from 'viable cells') and clones originated from heat-resistant spores and therefore derived from the small fraction of cells which reached late stages ('spore clones') behaved in the same way and exhibited the same spectrum of resistances as the original strain. The same was true for clones obtained from 'viable cell counts' or from 'octanol resistance counts' of mutants FD10 and FE9. The resistance spectrum of sporulating cultures is therefore genetically determined and decadent mutations introduce phenotypic heterogeneity into genetically homogeneous populations.

\section{Mapping of the SpoLI mutation}

Colonies of DB16 are recognized by their white colour ( $\mathrm{Pig}^{-}$). In addition, young colonies (15 h incubation) are killed by chloroform vapour and so can be identified by the chloroform replica technique $\left(\mathrm{Ch}^{\mathrm{s}}\right.$ phenotype). These characteristics permitted a genetic study of this decadent mutation. The $\mathrm{Pig}^{-} \mathrm{Ch}^{\mathrm{s}}$ phenotype was introduced by transformation into the $\mathrm{Spo}^{+}$strain PM7 (hisB2 metC3). Among $369 \mathrm{His}^{+}$and the same number of $\mathrm{Met}^{+}$

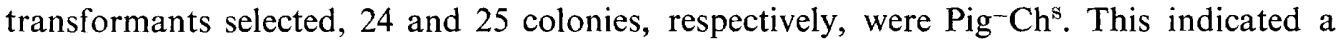
frequency of double transformation of $6.7 \%$, comparable with the frequency of double 


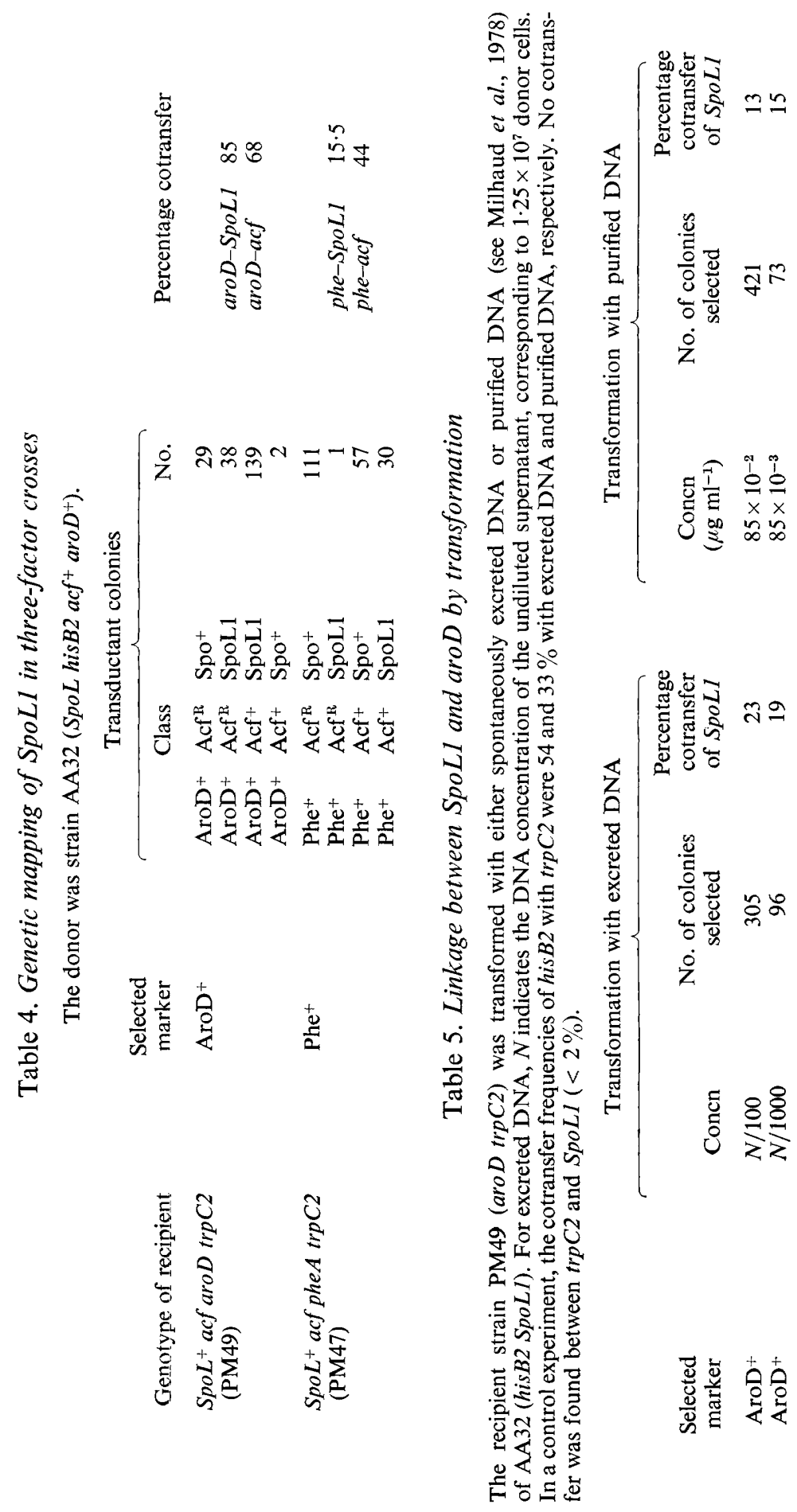




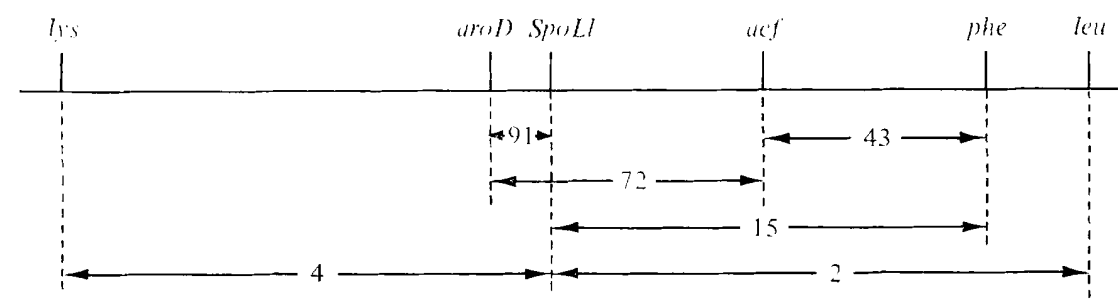

Fig. 10. Genetic location of the SpoL1 locus. The figures indicate the percentage cotransfer frequencies.

transformants for the two independent markers his B2 and metC3. Control experiments showed that the transformants exhibited a decadent phenotype similar to DB16. Thus the $\mathrm{Pig}^{-} \mathrm{Ch}^{\mathrm{s}}$ phenotype is apparently due to a single mutation, called SpoL1.* One of the transformants, AA32 (SpoL1 hisB2), was used in further genetic studies.

Transduction experiments with phage PBS1 indicated that three loci pheA1, lys- 1 and aroD were linked to $S p o L 1$ with cotransfer frequencies of 16,4 and $91 \%$, respectively (Table 3). The same results were obtained whether $S p o L I$ colonies were identified by their colour or by their sensitivity to chloroform vapour. The decadent phenotype was confirmed with a few selected transductants. Thus, the SpoL1 gene is apparently situated about halfway between phe $A$ and $l y s$, close to aroD. Since the two known loci situated between phe $A$ and lys, namely aroD (Hoch \& Nester, 1973) and acf (Ionesco et al., 1970), have not previously been precisely mapped, three-factor crosses were performed both to order these genes and to map SpoL1 with respect to them (Table 4). Assuming that among the selected $\mathrm{Aro}^{+}$and $\mathrm{Phe}^{+}$transductants the least frequent class corresponds to the double recombinants, the following gene orders were deduced: aroD-SpoL-acf (from the cross with PM49) and SpoL-acf-pheA (from the cross with PM47). Figure 10 shows the genetic map deduced from these transductions.

As suggested by the high cotransfer frequency betwen $S p o L 1$ and $\operatorname{aroD}$, the two markers are also linked by transformation. Using saturating concentrations of DNA, with PM49 $\left(\right.$ aro $\left.D \mathrm{Spo}^{+}\right)$as recipient and AA32 (arod $\left.{ }^{+} \mathrm{SpoL} 1\right)$ as donor, $55 \%$ of the colonies selected as $\mathrm{Aro}^{+}$were also SpoL1. In the reciprocal transformation, with AA32 as the recipient strain, $\mathrm{His}^{+}$transformants were first selected, and $\mathrm{Spo}^{+}$colonies were identified among them $; 40 \%$ of these were also $\mathrm{Aro}^{+}$. Since high DNA concentrations allow cotransformation of unlinked markers, transformation was repeated with limiting DNA concentrations. Similar results were obtained with dilutions of spontaneously excreted DNA and with purified DNA. The linkage between $S p o L 1$ and aroD was maintained with decreasing DNA concentrations (Table 5). The recombination frequency between the two markers was $83 \%$, compared with a recombination frequency between $\operatorname{trp} C 2$ and hisB2 of $44 \%$. No linkage was detected by transformation between SpoLI and acf.

Transformation experiments showed that FE9, the only decadent mutant which overproduces extracellular protease, carries two independent mutations: $S p o L 2$, responsible for the decadent phenotype, and Sco15, a control mutation leading to protease overproduction (see also Dod et al., 1978). Neither these loci nor the other decadent mutations have been mapped.

* Sporulation mutations are generally designated by Spo followed by a roman numeral indicating the stage of the block and a capital letter for the locus, e.g. SpoVE for a stage V mutation (Young \& Wilson, 1972). Since decadent mutants are heterogeneous with respect to the morphological block, the letter $L$ for 'late' is used. 


\section{DISCUSSION}

Decadent sporulation mutants are characterized by progressively declining frequencies of the sequentially appearing chemical resistances. Each resistance appears in populations of sporulating cultures with a genetically determined frequency. The various decadent mutants differ in the shape and slope of their resistance spectra. The order in which the frequencies of chemical resistances decrease follows the order of appearance of chemical resistances in sporulating cultures of wild-type strains (Milhaud \& Balassa, 1973) and confirms the sequential development of spore resistances.

The morphological studies confirm the existence of the 'decadent' phenotype: sporulating cells reach the successive morphological stages with decreasing frequencies. In some mutants, the majority of the cells remain blocked at stages III or IV; in others, many cells reach stages V or VI. In the latter, however, either the synthesis or the maturation of the cortex appears to be deficient.

It is difficult to deduce from the available data the exact correlation between the morphological stages and the chemical resistances, since the sporulating populations are heterogeneous and electron microscope studies examine 5 to $100 \%$ of the cell population while the chemical resistances can only be measured with precision in less than $10 \%$ of the population. It should be noted, however, that in two mutants, FA10 and FE9, one-third of the cells reach stage VI while only about $1 \%$ become resistant to chloroform and $0 \cdot 1 \%$ to heat. This observation can be explained in two ways: (i) although the cells appear to be at stage VI, one of the spore envelopes is abnormal, or (ii) the chemical resistances require the synthesis of some sporulation-specific product(s) in addition to the presence of normal spore envelopes. [This product cannot be DPA since DPA-less spores are chloroform-resistant (Balassa et al., 1979).]

One of the decadent mutations, SpoL1, was localized by transduction in the lys-phe region between aroD and $a c f$. It is linked by transformation to $\operatorname{aroD}$. This region is very rich in sporulation loci and contains a large number of late sporulation mutations blocked at stages III, IV or V (Piggot \& Coote, 1976). In the absence of fine structure mapping and of more detailed phenotypic studies it is difficult to decide whether one of these loci is identical with SpoLI or if the latter represents a new locus. The other decadent mutants have not yet been mapped but some of them present a phenotype sufficiently different from SpoLI to suppose that they correspond to one or more other loci.

The phenotype of the decadent mutants can be tentatively described as follows: during sporulation, each switch in the morphogenetic sequence occurs more slowly and with a lower probability than in the $\mathrm{Spo}^{+}$cells. The synthesis of extracellular protease, an early sporulation product, is apparently unaffected by decadent mutations while late events such as the synthesis of DPA and lysis of the sporangium do not take place. (Unfortunately biochemical events associated with intermediate stages were not measured.)

Sporulation is controlled by sequential gene activation (Balassa, 1971; Piggot \& Coote, 1976). The characteristics of the decadent mutations suggest that they are implicated in the quantitative control of sporulation. Their pleiotropic effects make it very unlikely that they involve a structural gene for a spore-specific product. Since the decadence is, in general, extended over at least three morphological stages, it is difficult to imagine that the quantities of a single sporulation-specific product would be affected.

The phenotype of decadent mutations can be explained if impaired function of a sporulation gene leads to only partial activation of the next gene in the sequence, which in turn induces the next gene only in a fraction of the cells and even there only to a lower level, and so on. This would result in a progressive decrease of what one could call the "flux of induction' and, as a consequence, in a low probability of switch at all the steps of the sporulation sequence (Balassa \& Yamamoto, 1970; Balassa, 1971). Some of the spore control ( $\mathrm{Sco}$ ) mutations also appear to affect the switch mechanism specifically (Balassa et al., 1974; 
Sousa et al., 1978). They differ from the decadent mutations in the overproduction of sporulation-associated proteins and in the fact that although the switch from one morphological stage to another is slowed down in these mutants, it affects all cells and, at the end of the process, most of them reach stage VI and heat resistance.

Other explanations which do not directly involve sequential gene activation are also possible. Thus, decadent mutants could be leaky for the production of a single gene product, necessary for all the specific events during a long period of the sporulation process or involved in energy production during sporulation. On the other hand, the simultaneous presence of two or more oligosporogenous mutations could lead to a phenotype close to that of the decadent mutants (Coote \& Mandelstam, 1973). This is not the case for DB16 and for FE9. For the other decadent mutants obtained by nitrosoguanidine-induced mutagenesis, the presence of multiple mutations cannot be excluded. If this were the case, however, one would expect two distinct, clearly defined blocks in the sporulation process, instead of the progressive 'decadence' observed over several morphological stages.

In conclusion, we suggest that the decadent mutations are single pleiotropic mutations which cause stepwise decrease of the activity of a whole set of sporulation genes. Further genetic and biochemical studies are necessary to confirm this hypothesis.

We thank Mrs E. Raulet and M. I. Barros for excellent technical assistance. This work was supported by grants from the Fondation pour la Recherche Médicale Française and from the Scientific Affairs Division of NATO. J.C. F. Sousa was a fellow of the Gulbenkian Foundation (Lisbon, Portugal).

\section{REFERENCES}

Balassa, G. (1969). Biochemical genetics of bacterial sporulation. I. Unidirectional pleiotropic interactions among genes controlling sporulation in Bacillus subtilis. Molecular and General Genetics 104, 73-103.

Balassa, G. (1971). The genetic control of spore formation in bacilli. Current Topics in Microbiology and Immunology 56, 99-192.

Balassa, G. \& Yamamoto, T. (1970). Biochemical genetics of bacterial sporulation. III. Correlation between morphological and biochemical properties of sporulation mutants. Molecular and General Genetics 108, 1-22.

Balassa, G., Dod, B., Milhaud, P., Serre, A., Silva, M. T. \& Sousa, J. (1974). The genetic control of late sporulation events in mutants of Bacillus subtilis: preliminary results. In Spore Research 1973, pp. 73-86. Edited by A. N. Barker, G. W. Gould \& J. Wolf. London: Academic Press.

Balassa, G., Milhaud, P., Raulet, E., Silva, M. T. \& SousA, J. C. F. (1979). A Bacillus subtilis mutant requiring dipicolinic acid for the development of heat-resistant spores. Journal of General Microbiology 110, 365-379.

Coote, J. G. \& Mandelstam, J. (1973). Use of constructed double mutants for determining the temporal order of expression of sporulation genes in Bacillus subtilis. Journal of Bacteriology 114, 1254-1263.

Dod, B., Balassa, G., Raulet, E. \& Jeannoda, V. (1978). Spore control (Sco) mutations in Bacillus subtilis. II. Sporulation and the production of extracellular proteases and amylase by Sco mutants. Molecular and General Genetics 163, 45-56.
Gould, G. W. \& Dring, G. J. (1974). Mechanisms of spore heat resistance. Advances in Microbial Physiology 11, 137-164.

Hoch, J. A. \& Nester, E. W. (1973). Gene enzyme relationship of aromatic acid biosynthesis in Bacillus subtilis. Journal of Bacteriology 116, 59-66.

Ionesco, H., Michel, J., Cami, B. \& Schaeffer, P. (1970). Genetics of sporulation in Bacillus subtilis. Journal of Applied Bacteriology 33, 13-24.

Milhaud, P. \& Balassa, G. (1973). Biochemical genetics of bacterial sporulation. IV. Sequential development of resistances to chemical and physical agents during sporulation of Bacillus subtilis. Molecular and General Genetics 125, 241-250.

Milhaud, P., Balassa, G. \& Zucca, J. (1978). Spore control ( $\mathrm{Sco}$ ) mutations in Bacillus subtilis. I. Selection and genetic mapping of Sco mutants. Molecular and General Genetics 163, 35-44.

Millet, J. \& Ryter, A. (1972). Mutants de Bacillus subtilis Marburg bloqués tardivement dans leur sporulation. Annales de l'Institut Pasteur 122, 395-406.

Piggot, P. J. \& Coote, J. G. (1976). Genetic aspects of bacterial endospore formation. Bacteriological Reviews 40, 908-962.

RYTER, A. (1965). Étude morphologique de la sporulation de Bacillus subtilis. Annales de l'Institut Pasteur 108, 40-60.

Ryter, A. \& Kellenberger, E. (1958). Étude au microscope électronique de plasmas contenant de l'acide désoxyribonucléique. I. Les nucléotides des bactéries en croissance active. Zeitschrift für Naturforschung 13b, 597-605. 
Sousa, J. C. F., Silva, M. T. \& Balassa, G. (1974).

Biochemical genetics of bacterial sporulation. V. Fine structure analysis of two sporulation mutants of Bacillus subtilis derepressed for late functions. Molecular and General Genetics 128, 261-272.

Sousa, J. C. F., Silva, M. T. \& Balassa, G. (1978). Spore control (Sco) mutations in Bacillus subtilis.
V. Electron microscope study of delayed morphogenesis. Molecular and General Genetics 163, 285-291.

YounG, F. E. \& WiLson, G. A. (1972). Genetics of Bacillus subtilis and other gram-positive sporulating bacilli. In Spores V, pp. 77-106. Edited by H. O. Halvorson, R. Hanson \& L. L. Campbell. Washington: American Society for Microbiology. 